\title{
Literature Study : Activity-Based Costing System
}

\author{
Larashati B'tari Setyaning ${ }^{1}$, Andriani Okta Fara Dita ${ }^{1}$ \\ ${ }^{1}$ Departmen of Civil Engineering, Faculty of Civil, Planning and Geo Engineering, Institut Teknologi Sepuluh \\ Nopember, Surabaya, Indonesia \\ Email: ${ }^{1}$ btari.larashati@gmail.com, ${ }^{2}$ andrianioktaf@gmail.com
}

\begin{abstract}
Abstrak
Meningkatnya persaingan memaksa perusahaan menjadi kompetitif. Daya saing dapat dicapai dengan menyampaikan nilai produk kepada konsumen dengan harga murah. Untuk mencapai hal tersebut diperlukan pendekatan biaya yang baik salah satunya adalah Activity-Based Costing System $(A B C)$. Dalam studi pustaka ini penulis membagi $A B C$ menjadi 3 bagian yaitu konsep $A B C$, tahapan dalam $A B C$ serta biaya dan manfaat penerapan $A B C$. ABC merupakan metode pendekatan biaya dengan menghitung biaya kegiatan untuk menghasilkan produk, baik barang maupun jasa dimana kegiatan tersebut membutuhkan sumber daya. Setelah melakukan studi pustaka, penulis menemukan persamaan dan ketimpangan diantara beberapa literatur kemudian menarik kesimpulan. Kesimpulan yang dapat diambil adalah bahwa sistem ABC digunakan oleh perusahaan untuk mendapatkan biaya produksi yang lebih akurat, biaya produksi yang akurat dapat meningkatkan keuntungan perusahaan dan kriteria perusahaan yang layak untuk menggunakan sistem $A B C$ adalah perusahaan dengan tingkat produk yang tinggi. keanekaragaman, terdapat persaingan yang ketat dengan perusahaan yang memproduksi produk serupa, serta biaya penerapan sistem $A B C$ yang rendah.
\end{abstract}

Keywords: Activity-Based Costing System, literature study

\begin{abstract}
Increasing competition forces companies to be competitive. Competitiveness can be achieved by conveying product value to consumers at low prices. To achieve this, a good cost approach is needed, one of which is the Activity-Based Costing System (ABC). In this literature study the authors divide $\mathrm{ABC}$ into 3 parts, namely the concept of $\mathrm{ABC}$, the stages in $\mathrm{ABC}$ and the costs and benefits of implementing $\mathrm{ABC}$. $\mathrm{ABC}$ is a cost approach method by calculating the cost of activities to produce products, both goods and services where these activities require resources. After conducting a literature study, the authors found similarities and inequalities among several literatures and then draw conclusions. The conclusion that can be drawn is that the ABC system is used by companies to get more accurate production costs, accurate production costs can increase company profits and the criteria for companies that are suitable for using the $\mathrm{ABC}$ system are companies with a high level of product diversity, there is intense competition with companies that produce similar products, as well as the cost of implementing the ABC system is low.
\end{abstract}

Keywords: Activity-Based Costing System, literature study

\section{Introduction}

Increasing technological developments and the implementation of free trade systems such as the AEC (Asean Economic Community) and APEC (Asia Pacific Economic Cooperatin), have resulted in increased global competition. This makes companies have to be competitive if they want to survive. Competitiveness can be achieved by implementing good cost management. Cost management is a philosophy, attitude and a series of ways to create value at the lowest cost [1]. To create value at the lowest cost there are a variety of cost approaches that can be taken. One approach that is popular and adopted by large companies such as Hewlett-Packard, DaimlerChrysler and IMB is ABC [1].

There are two approaches in determining costs in the accounting system, namely the traditional cost system (TCS) and the activity-based cost system (ABC). ABC is used to perfect TCS. TCS makes the assumption that volume is what underlies product costs, so TCS fails to allocate non- 
manufacturing costs that are also related to production, such as administrative and marketing costs. This can be solved by $\mathrm{ABC}$, because $\mathrm{ABC}$ uses activities starting from purchasing to selling as a basis for determining product costs. The accuracy of information about activities is the key to being able to implement $\mathrm{ABC}$ optimally. The accuracy of this activity information can assist companies in developing and implementing company strategies by providing accurate information about product costs, costs to serve customers, costs of negotiating with suppliers, and costs of supporting business processes within the company. In this paper, the author will review various literatures on cost management, especially in the $\mathrm{ABC}$ chapter. From the literature study, a complete picture of $\mathrm{ABC}$ will be obtained.

\section{Methods}

The methodology used is Systematic Literature Review (SLR) by looking for similarities and inequalities among several literatures and then concluding what has been read from some of the literature. This literature is focused on books that discuss ABC. Those books then combined, and content of the books is mapped by looking for similarities and differences in each book, especially in the $\mathrm{ABC}$ chapter.

\section{Result and Discussion}

\subsection{Concept of ABC System}

Activity-Based Cost (ABC) is a method for calculating costs based on the cost of activities carried out in producing products, both goods and services [2]. Activities are tasks carried out by companies to produce goods or services [2]. The rationale for this cost approach is that the product is the result of activities that use resources and resources require costs to obtain it [1]. To reduce the cost of the product, it is necessary to modify the activities required to produce the product [2]. The ABC system separates the costs for each activity and assigns costs to the product using a cost driver which is a determining factor for the amount of activity costs [3]. The ABC system can recognize for the production of two different batches of products, but which consume the same amount of activities from purchase, receipt and inspection, both products have the same activity costs. The ABC system recognizes a causal relationship between resource costs, cost drivers, activities and cost objects in determining activity costs which are used to determine product costs [1]. Based on the explanation above, it can be concluded that the ABC system is a cost approach method based on activities carried out by a company to produce goods and services, where these activities require resources and resources require costs.

\subsection{Stage of ABC System}

Four stages used in determining cost of goods and services using an activity-based costing system [2], namely: (1) Identification and classification of activities carried out in the production of a product; (2) Estimated costs required to carry out these activities; (3) Calculating the cost-driver rate for each activity; (4) Set product costs based on activity costs.

In designing an activity-based cost system, there are six stages [4], namely: (1) Identification, definition and classification of activities; (2) Determine the cost of resources into activities; (3) Assign secondary activity costs to primary activities; (4) Determine the cost of primary activities; (5) Calculating the rate of primary activity; (6) Assign activity costs into cost objects.

Developing an $\mathrm{ABC}$ system requires three steps [1], namely: (1) Identification of activities and resource costs; (2) Determine the cost of resources for activities; (3) Set activity costs for cost objects (products). The comparison of each stage based on the literature used can be seen in table 1 . 
Table 1. Comparison of ABC Stage

\begin{tabular}{ccc}
\hline Hilton et al, 2006 & Hansen \& Mowen, 2006 & Blocher et al, 2010 \\
\hline $\begin{array}{c}\text { Activity identification and } \\
\text { classification }\end{array}$ & $\begin{array}{c}\text { Identification and classification of } \\
\text { activity } \\
\text { Activity cost estimation }\end{array}$ & $\begin{array}{c}\text { Determine resources cost } \\
\text { Determine secondary activity costs } \\
\text { Determine primary activity costs } \\
\text { Calculate rate of primary activity }\end{array}$ \\
$\begin{array}{c}\text { Calculate cost driver rate } \\
\text { Determine product costs based on } \\
\text { activity costs }\end{array}$ & Determine activity costs & Determine resource costs for activity \\
\hline
\end{tabular}

\subsubsection{Activity Identification and Classifiaction}

To facilitate identification and classification, activities and resources are divided into 5 hierarchies [2], namely: (1) Unit level activities and resources, Activities undertaken, and resources required to produce one unit of product, ctivities and unit resources can be tracked directly in the product. (2) Batch level activities and resources, activities carried out and resources required to produce a group or batch of the same product. (3) Product level activities and resource: activities undertaken, and resources required to produce and sell specific products. (4) Consumer level activities and resources: activities undertaken, and resources required to serve certain consumers. (5) Facility level activities and resources: activities undertaken, and resources required to provide general capacity in producing goods or services.

For purposes of the cost approach, activities can be classified into primary and secondary activities [4]. Primary activities are activities that directly used to calculate the cost of final production, while secondary activities are activities that used to calculate the costs of primary activities [4]. The methods for identifying and classifying activities in ABC [2] are: (1) Top-down approach: this approach is carried out by middle and upper-level managers. The advantage of this approach is easy to do at a low cost. (2) Interview or participative approach: the advantage of this method is more accurate in identifying and classifying activities when compared to the top-down approach, because workers who are accustomed to doing these activities understand more about their work than supervisors or managers. (3) Recycling approach: this approach reuse documents related to activities or processes that were previously used for other purposes.

\subsubsection{Activity Cost Estimate}

In this stage the $\mathrm{ABC}$ team estimates the costs of the activities identified in the first stage by combining information about activities obtained through certain approaches and combining it with accounting data and other records [2]. Every activity requires resources, the resources used to carry out activities consist of labor, material, capital and energy [4]. Resources are an economic element needed to carry out activities [1].

\subsubsection{Calculate Cost Driver Rate}

Cost drivers are certain characteristics of an activity that cause costs to these activities. The cost-driver rate is the estimated cost of the resources used in the cost driver for each activity [2]. The cost-driver rate can calculated by dividing the cost of activity for a certain period by the volume of activity for that period. The cost driver must meet the following conditions: (1) has a causal relationship with the activities and costs, (2) countable, (3) can explain the use of resources in activities accurately, (4) calculation of resources for activities based on actual capacity in practice.

\subsubsection{Determine Product Cost Based on Activity Cost}

After knowing the activity costs which are calculated using the cost driver rate, the product cost can be found by adding up the activity costs. 


\subsection{The Benefits and Costs of Implementing the ABC System}

To implement $\mathrm{ABC}$ in a company, of course, requires more costs. These costs include providing additional recording systems, customizing computer systems and hiring consultants. Therefore, managers must decide carefully in deciding when to apply the $A B C$ system [2]. The benefits of implementing activity-based costing [1] include: (1) Produces a better profit measure: the ABC system provides a more accurate measurement of the activities that drive costs, so it can help managers to develop products and processes by making better decisions about product design, customer support and future projects. (2) Development in the production process: the ABC system provides information about which areas in the production process need improvement. (3) Produce better cost estimates: $\mathrm{ABC}$ is used by companies with a high level of product diversity. There is intense competition with companies that produce similar products, and the cost of implementing the ABC system is low.

\section{Conclusions}

From the findings described above, the following conclusions were drawn: (1) ABC system is used by companies to get more accurate production costs, (2) accurate production costs can increase company profits through decision making about product pricing, product lines and market segments, (3) the criteria for companies that are suitable for using the ABC system are companies with a high level of product diversity, there is intense competition with companies that produce similar products, and the costs for implementing the $\mathrm{ABC}$ system are low.

\section{References}

[1] Blocher. Edward J., Stout. David E., Cokins. Gary. 2010. Cost Management: A Strategic Emphasis, Fifth Edition. New York: McGraw-Hill.

[2] Hilton. Ronald W., Maher. Michael W., Selto. Frank H. 2006. Cost Management Strategies for Business Decision. New York: McGraw-Hill.

[3] Drury. Colin. Management and Cost Accounting, Tenth Edition. 2018. United Kingdom: Cengange.

[4] Hansen. Dor R., Mowen. Maryanne M. 2006. Cost Management Accounting and Control, Fifth Edition. USA: Thomson South-Western. 